\title{
The Potential Role of 6-gingerol and 6-shogaol as ACE Inhibitors in Silico Study
}

\author{
Yohanes Bare $^{1 *}$, Maria Helvina ${ }^{2}$, Gabriella Chandrakirana Krisnamurti ${ }^{3}$, Mansur $\mathrm{S}^{1}$ \\ ${ }^{1}$ Biology Education Study Program, Faculty of Teaching and Training Education, Universitas Nusa Nipa \\ Jl. Kesehatan No. 3 Alok Tim, East Nusa Tenggara, Indonesia. 22388. \\ ${ }^{2}$ Primary Education Study Program, Faculty of Teaching and Training Education, Universitas Nusa Nipa \\ Jl. Kesehatan No. 3 Alok Tim, East Nusa Tenggara, Indonesia. 22388. \\ ${ }^{3}$ Biotechnology Program, School of Bioresources and Technology, King Mongkut's University of Technology Thonburi \\ 126 Pracha Uthit Rd, Bang Mot, Thung Khru, Bangkok 10140, Thailand. \\ *Email: bareyohanes@gmail.com
}

\begin{abstract}
Hypertension has become the third highest cause of death in Indonesia. The condition is correlated with angiotensin-converting enzyme (ACE), and possibly managed with the use of drugs. In addition, some natural compounds, including 6-shogaol and 6-gingerol from ginger, are used to decrease blood pressure. However, the mechanism and binding site of these compounds to ACE protein is currently unclear. This study, therefore, aims to investigate the potential role of these compounds as an angiotensinconverting enzyme inhibitor. The ACE protein was downloaded from Protein Data Bank (PDB) database with the ID: 3bkk, while the 6-shogaol (CID: 5281794) and 6-gingerol (CID: 44559528) ligands were obtained from the PubChem database. Meanwhile, molecular docking was established using HEX 8.0.0 software. The analysis examined the amino acid residues and the bonds formed from these interactions. According to the results, 14 amino acid residues were formed by the interaction between 6-shogaol and ACE, while the interaction between 6-gingerol and ACE formed eight amino acids. Also, 13 amino acid residues in the novelty binding site of ACE were discovered to be blocked by the ligands from ginger. Therefore, the compounds have potential roles as inhibitors, and this possibly helps to prevent regulation of the renin-angiotensin system. These interactions also formed hydrogen bonds, as well as electrostatic, unfavorable, and hydrophobic sites, making the binding stronger than others.
\end{abstract}

Keywords: ACE; amino acid residue; ginger; 6-gingerol, 6-shogaol

Article History: Received 04 September 2020; Received in revised form 30 September 2020; Accepted 01 November 2020; Available online 30 December 2020

How to Cite This Article: Bare Y, Helvina M, Krisnamurti GC, S M. 2020. The potential role of 6-gingerol and 6-shogaol as ACE inhibitors in silico study. Biogenesis: Jurnal Ilmiah Biologi. vol 8(2): 210-218. doi: https://doi.org/10.24252/bio.v8i2.15704.

\section{INTRODUCTION}

Type 2 Diabetes Mellitus (T2DM) is a metabolic disease characterized by insulin resistance, hyperglycemia, and pancreatic $\beta$ cell dysfunction (Ashcroft \& Rorsman, 2012; Hameed et al., 2015; Bare et al., 2018). The World Health Organization (WHO) predicts T2DM prevalence to have increased in Indonesia by 2030. According to Tarigan et al. (2018), the condition is closely related to hypertension, the third highest cause of death within the country. Hypertension is related to the Angiotensin-converting enzyme (ACE), and this protein hydrolyzes and converts inactive angiotensin-I to active angiotensin-II (Ouwerkerk et al., 2017; Messerli et al., 2018). Synthetic drugs are able to maintain hypertension by reducing blood pressure. However, these drugs tend to have side effects. Therefore, the accuracy of drugs ought to be evaluated in order to achieve the therapeutic goals, as redactors of cardiovascular morbidity and mortality. The administration of inappropriate antihypertensive medicine tends to increase blood pressure and lead to heart attack, stroke, kidney disease, as well as other ailments. Traditional treatment using natural herbs has provided an effective alternative for reducing blood pressure. The bioactive compounds in herbs are less toxic compared to synthetic drugs. Furthermore, natural medicine helps to exploit biological resources (Chiou et al., 2017; Kesuma et al., 2018). Various natural compounds have been reported as ACE inhibitors. These include quercetin (Larson et al., 2010; Muhammad \& Fatima, 2015; Liu et al., 2020), chlorogenic acid (Agunloye \& Oboh, 2018; Bare et al., 2019a), hyperin (Huang et al., 2017), tannic acid, flavonoid, and phenolic compounds (Nileeka-Balasuriya \& Vasantha-Rupasinghe, 2011; Al Shukor et al., 2013).

Ginger (Zingiber officinale) is one of the natural herbs to reduce blood pressure. In 
Sikka, ginger is used to treat skin disease, strokes, hypertension, and diabetes mellitus. The herb also contains 6-gingerol, 6-shogaol, 8gingerol, 8-shogaol, 10-gingerol, and 10shogaol and other polyphenols (Mao et al., 2019) with anti-diabetic (Shivanna et al., 2013), anti-hypertensive property (Akinyemi et al., 2013; Bare et al., 2019b). According to the in-vitro study, ginger extract prevents hypertension and manages blood pressure (Akinyemi et al., 2013). Furthermore, the herb contains bioactive compounds with antagonistic effects on ACE-1 (Liu et al., 2013; Zhao et al., 2018; Bare et al., 2019b). However, the inhibition mechanism of these compounds on ACE is not currently clear. Therefore, this study analyzed the bioactive compounds in ginger as appropriate nutrients for treating genomic hypertension through ACE inhibition.

\section{MATERIALS AND METHODS}

Ligand and Protein Preparation. The model ACE (ID: 3bkk) was obtained from the Protein Data Bank (PDB) database http://www.rcsb.org/pdb/home/home.do, while the 6-shogaol ligand (CID: 5281794) and 6gingerol (CID: 44559528) were acquired from the PubChem database. Subsequently, the energy of these ligands were minimized using the PyRx virtual screening program Open Babel tool and converted from SDF into PDB files. The protein obtained were then cleaned to extract water molecules and binding ligands, using Discovery Studio Client 4.1 (Bare et al., 2019a).

Molecular Interaction. HEX 8.0.0 software was used to dock the prepared protein and ligand. The docking parameters utilized were Shape, electro and DARS. Subsequently, the protein-ligand's 3D model, ACE binding sites, interaction types, and Ramachandran plot were determined and visualized using Discovery Studio Client 4.1 software (Bare et al., 2019b).

\section{RESULTS AND DISCUSSION}

The interaction between 6-gingerol and ACE was discovered to occur in eight amino acid residues active sites. Fig. 1c and Fig. 1d show amino acid residues involved in this interaction, TYR253, HIS383, HIS387, ASP377, ALA354, GLU162, ASN167, and GLU376.

a

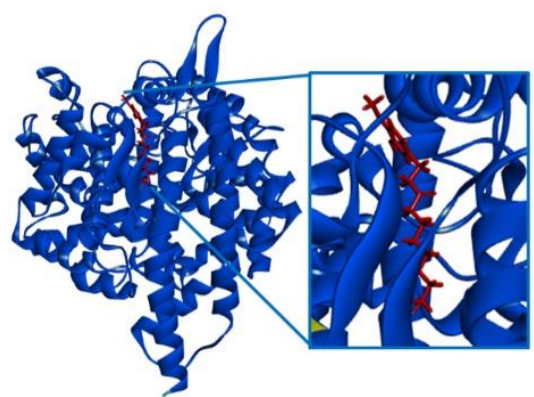

b
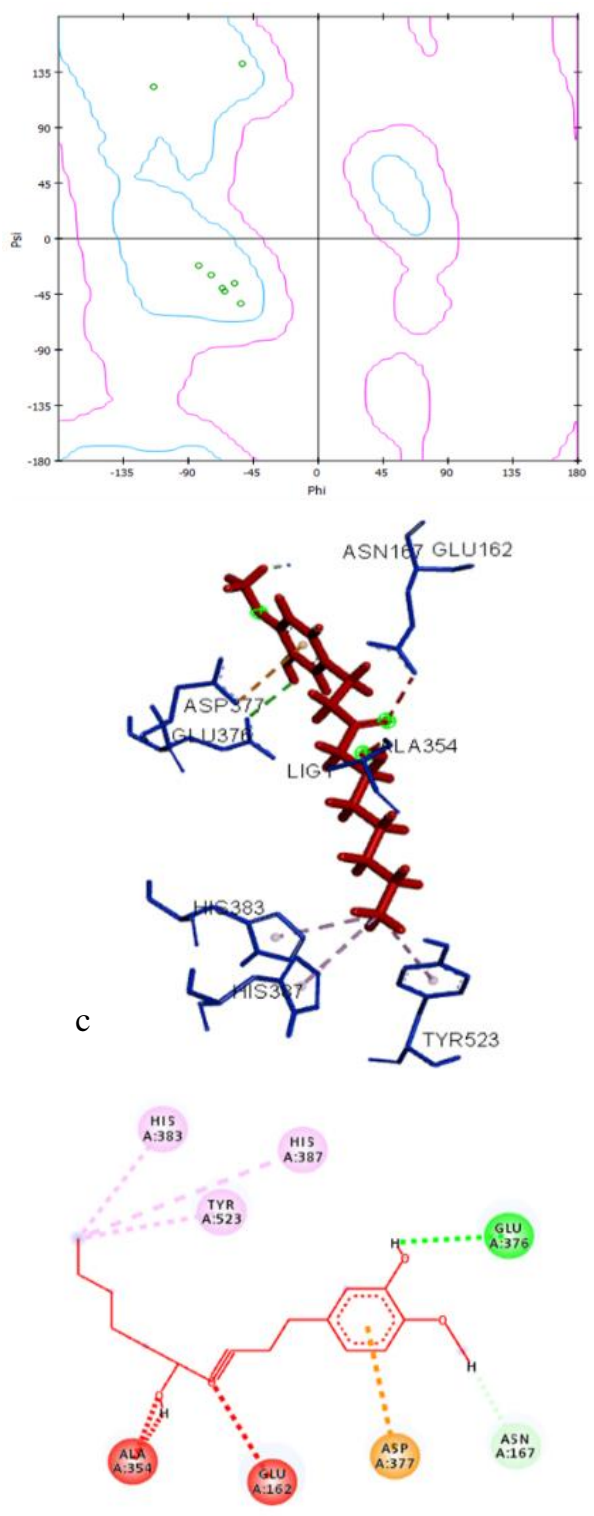

d
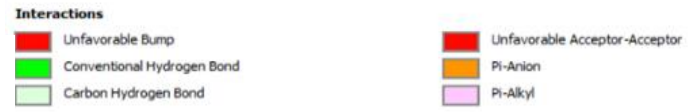

Fig. 1. The Interactions between ACE and 6-gingerol: a. 6-Gingerol bonding area in ACE; b. Ramachandran plot complex 6-gingerol-ACE; c. 3D active side ACE against 6-gingerol; d. 2D active side ACE, against 6-gingerol. 
The types of bond discovered between the ligand and protein were Pi-Alkyl (TYR253, HIS383, HIS387), Pi-Anion (ASP377), unfavourable bump (ALA354, GLU162), carbon hydrogen bond (ASN167) and convention hydrogen bond (GLU376). According to Table 1, the binding energy of the interaction between 6-gingerol and ACE was $248.3 \mathrm{cal} / \mathrm{mol}$. a
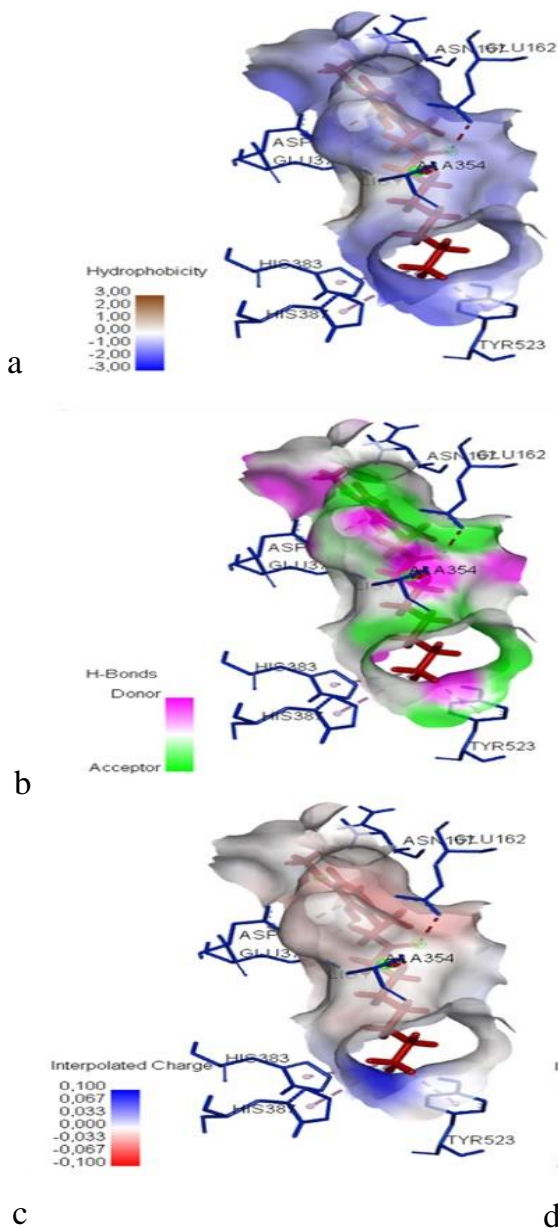
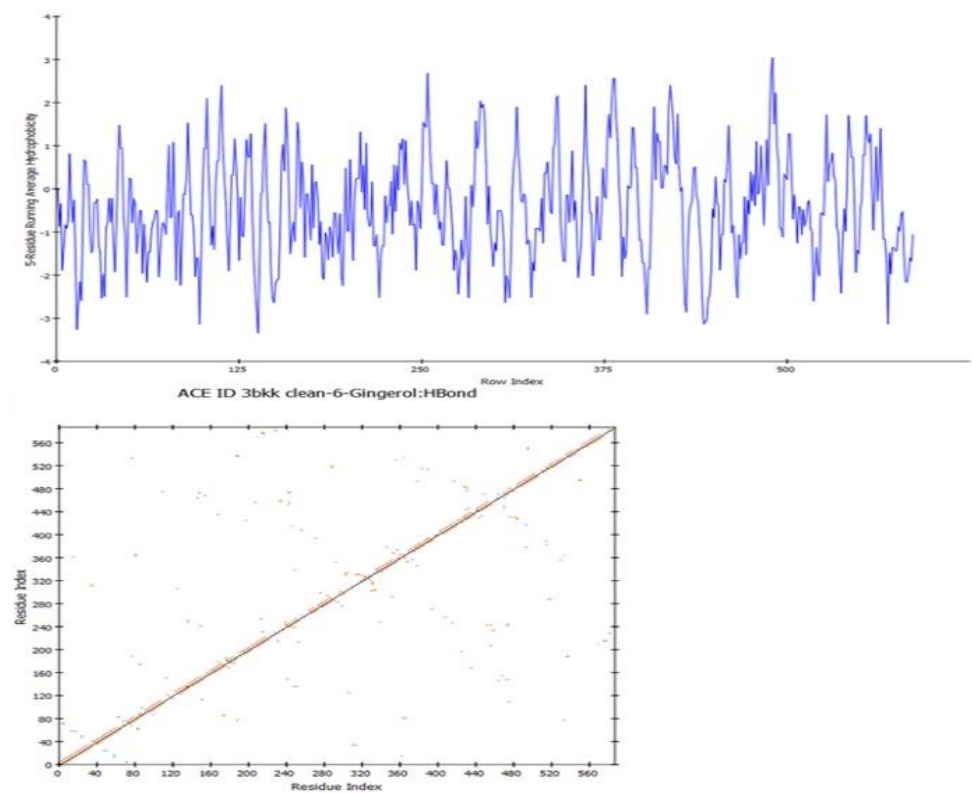

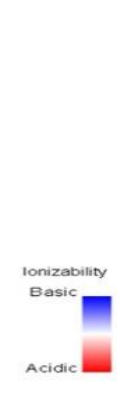

d

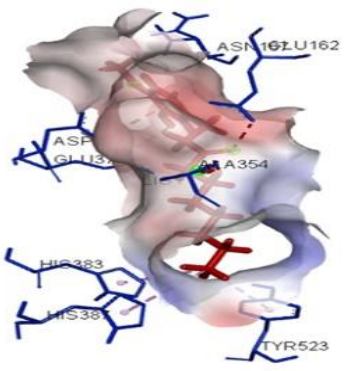

e

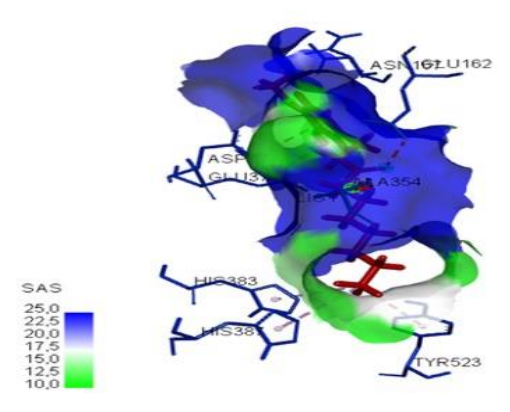

Fig. 2. The physicochemical complex of ACE-6-gingerol: a. hydrophobicity, and ACE-6 gingerol hydrophobicity plot; b. hydrogen bond and hydrogen bond plot ACE-6 gingerol; c. active side load of ACE-6 gingerol; d. ionization; e. solvent accessible surface (SAS).

Table 1. Interaction between 6-gingerol, 6-shogaol and angiotensin-converting enzyme I (ACE).

\begin{tabular}{|c|c|c|c|c|c|c|c|}
\hline Complex & $\begin{array}{l}\text { Binding } \\
\text { energy } \\
\text { (cal/mol) }\end{array}$ & Interaction & Distance & Category & Types & $\begin{array}{l}\text { From } \\
\text { Chemistry }\end{array}$ & $\begin{array}{l}\text { To } \\
\text { Chemistry }\end{array}$ \\
\hline \multirow[t]{7}{*}{$\begin{array}{l}\text { 6- } \\
\text { Gingerol- } \\
\text { ACE }\end{array}$} & -248.3 & $\begin{array}{l}\text { :LIG1:H - } \\
\text { A:GLU376:OE1 }\end{array}$ & 272.127 & $\begin{array}{l}\text { Hydrogen } \\
\text { Bond }\end{array}$ & $\begin{array}{l}\text { Conventional } \\
\text { Hydrogen } \\
\text { Bond }\end{array}$ & H-Donor & H-Acceptor \\
\hline & & $\begin{array}{l}\text { :LIG1:H - } \\
\text { A:ASN167:OD1:B }\end{array}$ & 196.649 & $\begin{array}{l}\text { Hydrogen } \\
\text { Bond }\end{array}$ & $\begin{array}{l}\text { Carbon } \\
\text { Hydrogen } \\
\text { Bond }\end{array}$ & H-Donor & H-Acceptor \\
\hline & & $\begin{array}{l}\text { A:ASP377:OD1 - } \\
\text { :LIG1 }\end{array}$ & 454.176 & Electrostatic & Pi-Anion & Negative & Pi-Orbitals \\
\hline & & A:HIS383 - :LIG1:C & 408.155 & Hydrophobic & Pi-Alkyl & Pi-Orbitals & Alkyl \\
\hline & & A:HIS387 - :LIG1:C & 497.361 & Hydrophobic & Pi-Alkyl & Pi-Orbitals & Alkyl \\
\hline & & A:TYR523 - :LIG1:C & 49.363 & Hydrophobic & Pi-Alkyl & Pi-Orbitals & Alkyl \\
\hline & & $\begin{array}{l}\text { A:ALA354:N - } \\
\text { :LIG1:H }\end{array}$ & 18.073 & Unfavorable & $\begin{array}{l}\text { Unfavorable } \\
\text { Bump }\end{array}$ & Steric & Steric \\
\hline
\end{tabular}




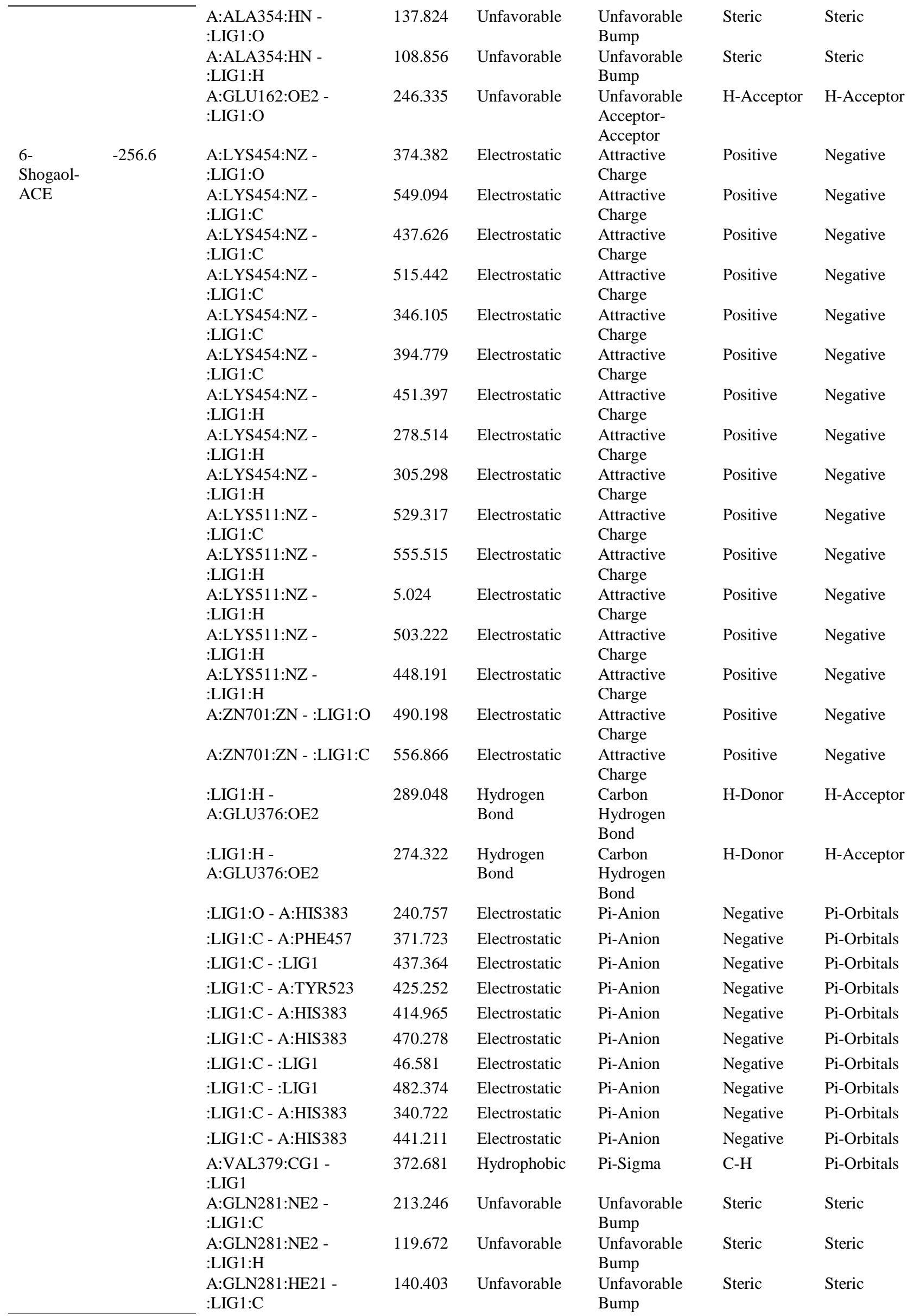




\begin{tabular}{|c|c|c|c|c|c|}
\hline $\begin{array}{l}\text { A:GLN281:HE21 - } \\
\text { :LIG1:H }\end{array}$ & $\begin{array}{l}0.80270 \\
2\end{array}$ & Unfavorable & $\begin{array}{l}\text { Unfavorable } \\
\text { Bump }\end{array}$ & Steric & Steric \\
\hline $\begin{array}{l}\text { A:GLU376:OE1 - } \\
\text { :LIG1:H }\end{array}$ & 468.055 & Unfavorable & $\begin{array}{l}\text { Unfavorable } \\
\text { Negative- } \\
\text { Negative }\end{array}$ & Negative & Negative \\
\hline $\begin{array}{l}\text { A:GLU376:OE1 - } \\
: L I G 1: H\end{array}$ & 420.813 & Unfavorable & $\begin{array}{l}\text { Unfavorable } \\
\text { Negative- } \\
\text { Negative }\end{array}$ & Negative & Negative \\
\hline $\begin{array}{l}\text { A:GLU376:OE2 - } \\
\text { :LIG1:O }\end{array}$ & 444.374 & Unfavorable & $\begin{array}{l}\text { Unfavorable } \\
\text { Negative- } \\
\text { Negative }\end{array}$ & Negative & Negative \\
\hline $\begin{array}{l}\text { A:GLU376:OE2 - } \\
\text { :LIG1:C }\end{array}$ & 508.313 & Unfavorable & $\begin{array}{l}\text { Unfavorable } \\
\text { Negative- } \\
\text { Negative }\end{array}$ & Negative & Negative \\
\hline $\begin{array}{l}\text { A:GLU376:OE2 - } \\
\text { :LIG1:C }\end{array}$ & 552.568 & Unfavorable & $\begin{array}{l}\text { Unfavorable } \\
\text { Negative- } \\
\text { Negative }\end{array}$ & Negative & Negative \\
\hline $\begin{array}{l}\text { A:GLU376:OE2 - } \\
\text { :LIG1:C }\end{array}$ & 328.296 & Unfavorable & $\begin{array}{l}\text { Unfavorable } \\
\text { Negative- } \\
\text { Negative }\end{array}$ & Negative & Negative \\
\hline $\begin{array}{l}\text { A:GLU376:OE2 - } \\
\text { :LIG1:H }\end{array}$ & 519.856 & Unfavorable & $\begin{array}{l}\text { Unfavorable } \\
\text { Negative- } \\
\text { Negative }\end{array}$ & Negative & Negative \\
\hline $\begin{array}{l}\text { A:GLU376:OE2 - } \\
\text { :LIG1:H }\end{array}$ & 466.512 & Unfavorable & $\begin{array}{l}\text { Unfavorable } \\
\text { Negative- } \\
\text { Negative }\end{array}$ & Negative & Negative \\
\hline $\begin{array}{l}\text { A:GLU376:OE2 - } \\
\text { :LIG1:H }\end{array}$ & 463.439 & Unfavorable & $\begin{array}{l}\text { Unfavorable } \\
\text { Negative- } \\
\text { Negative }\end{array}$ & Negative & Negative \\
\hline $\begin{array}{l}\text { A:GLU376:OE2 - } \\
\text { :LIG1:H }\end{array}$ & 514.395 & Unfavorable & $\begin{array}{l}\text { Unfavorable } \\
\text { Negative- } \\
\text { Negative }\end{array}$ & Negative & Negative \\
\hline $\begin{array}{l}\text { A:GLU376:OE2 - } \\
\text { :LIG1:H }\end{array}$ & 378.092 & Unfavorable & $\begin{array}{l}\text { Unfavorable } \\
\text { Negative- } \\
\text { Negative }\end{array}$ & Negative & Negative \\
\hline $\begin{array}{l}\text { A:ASP415:OD2 - } \\
\text { :LIG1:H }\end{array}$ & 558.987 & Unfavorable & $\begin{array}{l}\text { Unfavorable } \\
\text { Negative- } \\
\text { Negative }\end{array}$ & Negative & Negative \\
\hline $\begin{array}{l}\text { A:ASP453:OD1 - } \\
\text { :LIG1:O }\end{array}$ & 442.964 & Unfavorable & $\begin{array}{l}\text { Unfavorable } \\
\text { Negative- } \\
\text { Negative }\end{array}$ & Negative & Negative \\
\hline $\begin{array}{l}\text { A:ASP453:OD1 - } \\
\text { :LIG1:O }\end{array}$ & 488.702 & Unfavorable & $\begin{array}{l}\text { Unfavorable } \\
\text { Negative- } \\
\text { Negative }\end{array}$ & Negative & Negative \\
\hline $\begin{array}{l}\text { A:ASP453:OD1 - } \\
\text { :LIG1:C }\end{array}$ & 556.631 & Unfavorable & $\begin{array}{l}\text { Unfavorable } \\
\text { Negative- } \\
\text { Negative }\end{array}$ & Negative & Negative \\
\hline $\begin{array}{l}\text { A:ASP453:OD1 - } \\
\text { :LIG1:H }\end{array}$ & 53.632 & Unfavorable & $\begin{array}{l}\text { Unfavorable } \\
\text { Negative- } \\
\text { Negative }\end{array}$ & Negative & Negative \\
\hline $\begin{array}{l}\text { A:ASP453:OD1 - } \\
\text { :LIG1:H }\end{array}$ & 558.376 & Unfavorable & $\begin{array}{l}\text { Unfavorable } \\
\text { Negative- } \\
\text { Negative }\end{array}$ & Negative & Negative \\
\hline $\begin{array}{l}\text { A:ASP453:OD2 - } \\
\text { :LIG1:C }\end{array}$ & 41.829 & Unfavorable & $\begin{array}{l}\text { Unfavorable } \\
\text { Negative- } \\
\text { Negative }\end{array}$ & Negative & Negative \\
\hline $\begin{array}{l}\text { A:ASP453:OD2 - } \\
\text { :LIG1:H }\end{array}$ & 516.422 & Unfavorable & $\begin{array}{l}\text { Unfavorable } \\
\text { Negative- } \\
\text { Negative }\end{array}$ & Negative & Negative \\
\hline $\begin{array}{l}\text { A:ASP453:OD2 - } \\
: L I G 1: H\end{array}$ & 448.684 & Unfavorable & $\begin{array}{l}\text { Unfavorable } \\
\text { Negative- } \\
\text { Negative }\end{array}$ & Negative & Negative \\
\hline $\begin{array}{l}\text { A:ASP453:OD2 - } \\
\text { :LIG1:H }\end{array}$ & 353.509 & Unfavorable & $\begin{array}{l}\text { Unfavorable } \\
\text { Negative- } \\
\text { Negative }\end{array}$ & Negative & Negative \\
\hline
\end{tabular}




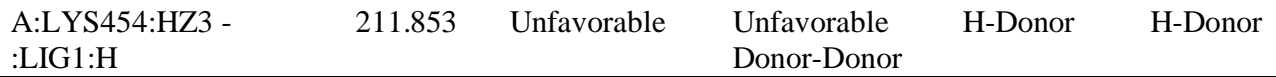

Based on Fig. 2a, the interaction between 6-gingerol and ACE indicates low hydrophobicity on the surface of the ligand. Fig. $2 b$ and Table 1 show the 6-gingerol compound also functions as a donor and acceptor of ACE in GLU376 and ASN167, while Fig. 2c and Fig. 2d indicate the 6-gingerol compound tends to be neutral, thus the ligand is zero charged. According to Fig. 2e, the value of the solvent-accessible surface (SAS) for 6gingerol surface is relatively high. SAS values are related to the van der Waals forces between ligands and ACE proteins.

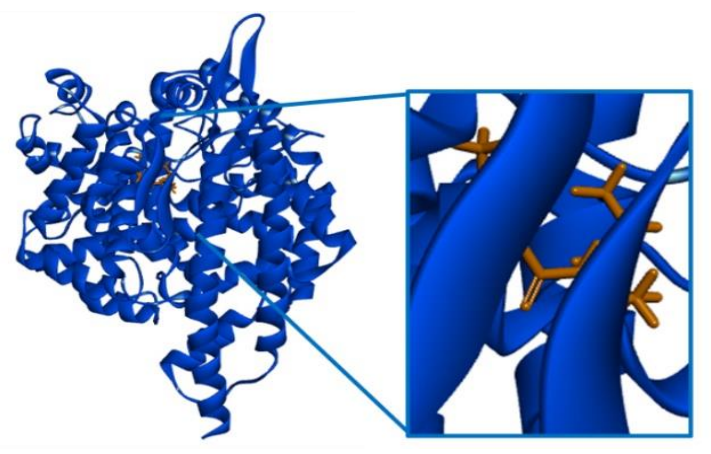

a

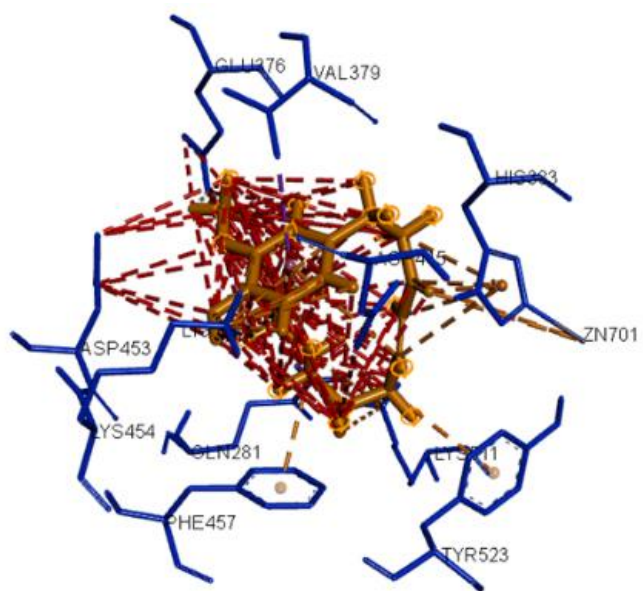

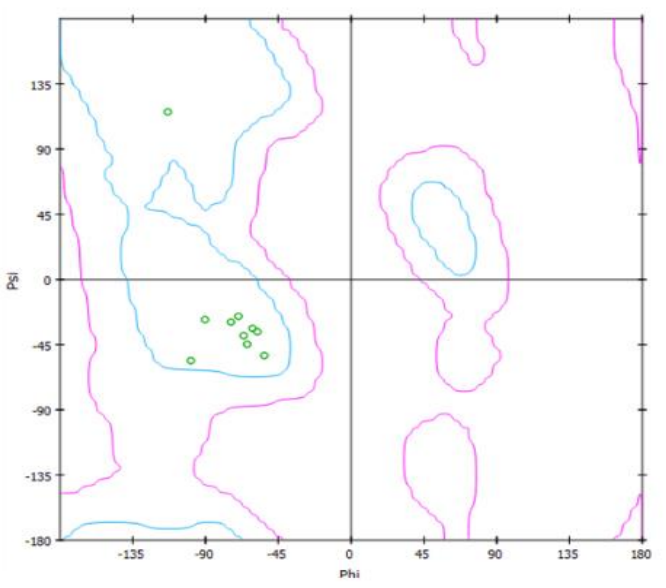

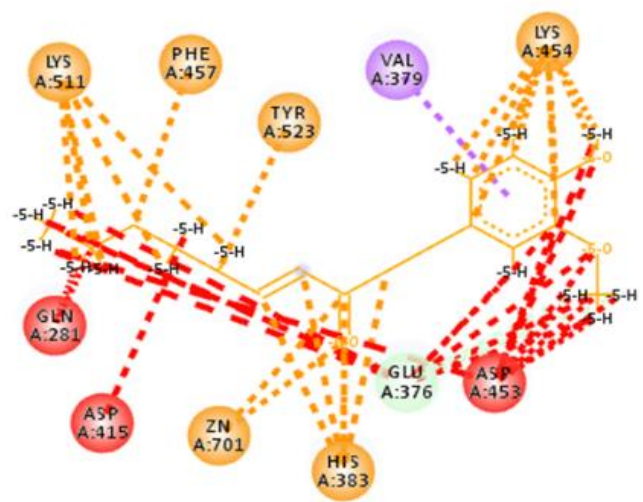

Interactions

Unfayorable Bump

Attractive Charge

Carbon Hydrogen Bond

Unfavorable Negative-Negative

Fig. 3. The complex 6-shogaol-ACE: a. 6-Shogaol-ACE bonding area; b. Ramachandran plot complex 6-shogaol-ACE; c. 3D active side 6-Shogaol-ACE; d. 2D active side 6-Shogaol-ACE.

The 6-shogaol-ACE complex exhibited a potential mechanism to inactivate the ACE conformation. Fig. 3c and Fig. 3d show the complex's active sites performing functional inhibition of ACE. These are GLU376 (hydrogen Bond type Carbon hydrogen), LYS454, LYS511, ZN701 (electrostatic tractive charge), HIS383, PHE457, TYR523, HIS383 (electrostatic Pi-Anion), VAL379 (hydrophobic Pi-Sigma), GLN281 (unfavorable bump), GLU376, ASP145, ASP453 (unfavorable negative-negative), LYS454 (unfavorable donor-donor). Meanwhile, Table 1 shows the binding energy of 6-shogaol-ACE was $-256.6 \mathrm{cal} / \mathrm{mol}$. This is typically quite strong to interact with the protein. 


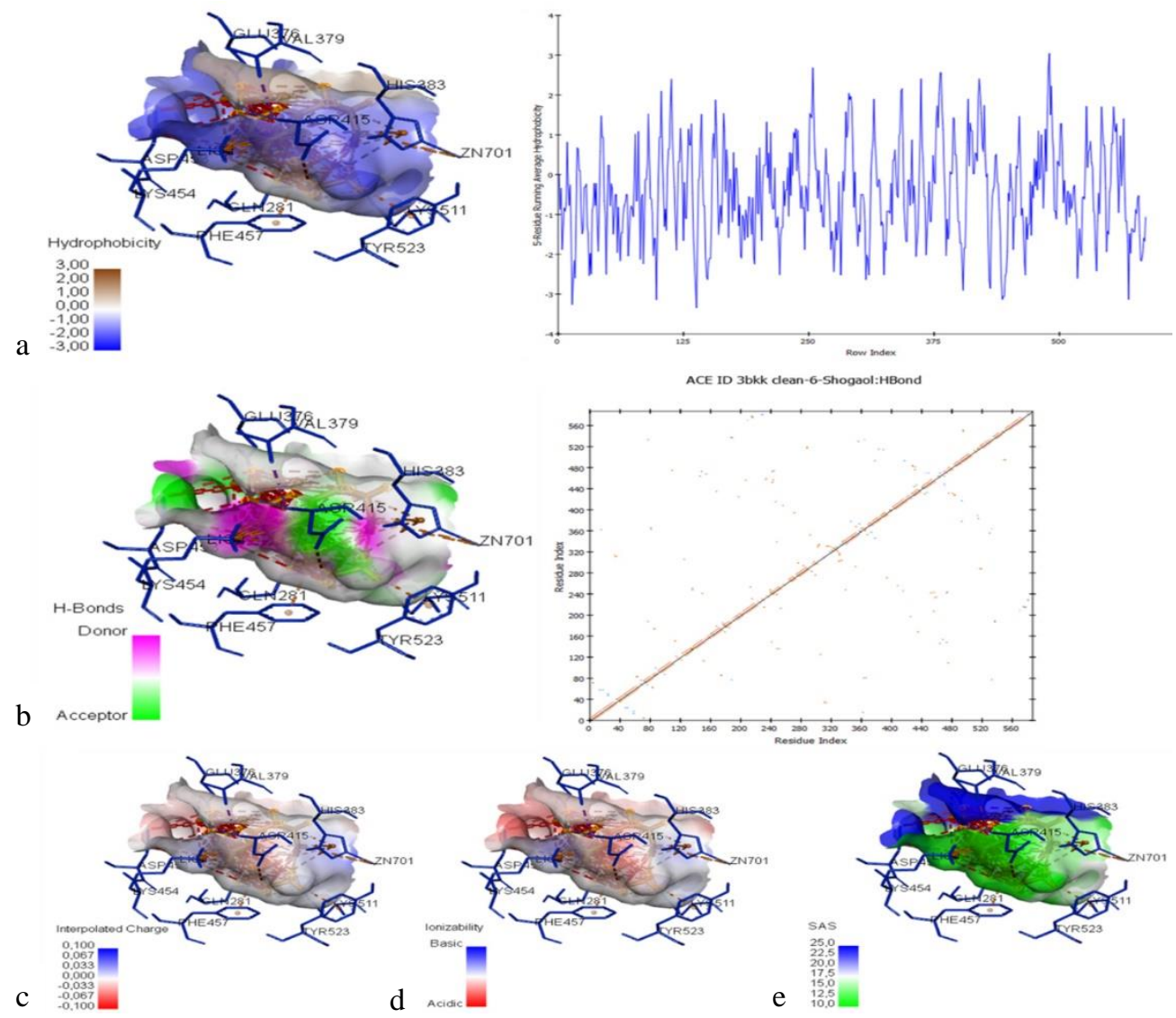

Fig. 4. The physicochemical complex 6-shogaol-ACE: a. hydrophobicity and the 6-shogaol-ACE hydrophobicity plot; b. hydrogen bond and hydrogen bond plot 6-shogaol-ACE; c. 6-shogaol-ACE active side load; d. ionization. e. solvent accessible surface (SAS).

Fig. 4a shows the low hydrophobicity level of 6-shogaol-ACE, denoted by blue color. Meanwhile Fig. $4 \mathrm{~b}$ and Table 1 show a potential residue, GLU376 capable of functioning as an ACE donor or acceptor of ACE. Fig. $4 c$ and Fig. $4 \mathrm{~d}$ show the 6-shogaol-ACE complex's zero charge, denoted by brown color. Based on Fig. $4 \mathrm{e}$, the complex has a high solvent-accessible surface (SAS) value, depicted by green color.

The interaction between 6-gingerol, 6shogaol, and ACE indicated positive results. According to Table 1, twenty amino acid residues performed as ACE active sites, leading ACE inactivation. A study by Ouwerkerk et al. (2017) stated several bioactive compounds significant for reducing the pathological impact on metabolism are currently being studied, while Al Shukor et al. (2013) reported molecular interactions between ACE inhibitors and the ACE binding site from plant phenolic compound in twelve amino acid residues. Similarly, 6 of these 12 amino acid residues were found to interact with the ligand in this study. These are TYR523, ALA354, LYS511, GLN281, ASP453, and ASP415. Meanwhile, Muhammad \& Fatimah (2015) reported other amino acid residues capable of binding with quercetin glycosides. These are ARG124, TYR135, ILE204, ALA208, GLU216, TYR215, and GLU96. This study also discovered novel binding sites from amino acid residues interacting with 6-gingerol and 6shogaol. These are TYR253, HIS383, HIS387, ASP377, GLU162, ASN167, GLU376, ZN701, HIS383, PHE457, VAL379, ASP145, and LYS454, and these are different from the quercetin and phenolic compound binding sites. In addition, the presence of several hydrogen bonds in the ligand-protein complex suggested strong binding (Bare et al., 2019b) Candrakirana, 2019; Kataria \& Khatkar, 2019). These bonds also promoted ligand binding affinities and stabilized the ligand-protein interaction (Zhou et al., 2012). The lower binding distance between ALA354 and 6gingerol leads to the formation of a stronger and 
tighter hydrogen bond, compared to the others (Santoso et al., 2016).

ACE inhibition is a critical stage of hypertension treatment because ACE has a crucial role in regulating the renin-angiotensin system (Guang et al., 2012; Liao et al., 2019). This method has a positive effect on therapy and has been linked to improved health, outside of blood pressure regulation (Bhullar et al., 2014). Liu et al. (2013) reported 6-gingerol to be a molecular target drug for curving hypertension. This study also proposed the molecular interaction this compound and another amino acid residue. Meanwhile, Akinyemi et al. (2013) and Zhao et al. (2018) stated ginger varieties inhibited ACE and also protected the heart from $\mathrm{Fe}^{2+}$ - and SNP-induced lipid peroxidation. Recent research also showed ginger extract influences blood pressure and lipid level in hypertensive and hyperlipidemic Wistar rats model (Sanghal et al., 2011, Sahardi \& Makpol, 2019). Similarly, a study by Akinyemi et al. (2014) reported ginger extract to exhibit ACE inhibitory activity. The interaction between ligan and protein has a positive impact, as ACE inhibitor was produced by renin to convert angiotensin I into angiotensin II. Also, Sahardi \& Makpol (2019), disclosed ginger is able to reduce the blood pressure of hypertension patients, as well as lipid peroxidation in the heart.

\section{CONCLUSION}

This study confirmed the binding of 6shogaol and 6-gingerol to ACE protein is tight, and the complex formed possibly has potential ACE inhibitory activity within ACE active sites. This interaction was observed to occur in twenty amino acid residues. The interaction also formed hydrogen bonds, electrostatic, unfavorable, and hydrophobic bonds, making binding stronger, compared to others.

\section{REFERENCES}

Agunloye OM, Oboh G. 2018. Caffeic acid and chlorogenic acid: evaluation of antioxidant effect and inhibition of key enzymes linked with hypertension. Journal of Food Biochemistry. vol 42(4): $1-10$.

doi: https://doi.org/10.1111/jfbc.12541.

Akinyemi AJ, Ademiluyi AO, Oboh G. 2013. Aqueous extracts of two varieties of ginger (Zingiber officinale) inhibit angiotensin I-converting enzyme, Iron(II), and sodium nitroprusside-induced lipid peroxidation in the rat heart in vitro. Journal of Medicinal Food. vol 16(7): 641-646. doi: https://doi.org/10.1089/jmf.2012.0022.

Akinyemi AJ, Ademiluyi AO, Oboh G. 2014. Inhibition of angiotensin-I-converting enzyme activity by two varieties of ginger (Zingiber officinale) in rats fed a high cholesterol diet. Journal of Medicinal Food. vol 17(3): 317-323. doi: https://doi.org/10.1089/jmf.2012.0264.

Al Shukor N, Van Camp J, Gonzales GB, Staljanssens D, Struijs K, Zotti MJ, Raes K, Smagghe G. 2013. Angiotensin-converting enzyme inhibitory effects by plant phenolic compounds: A study of structure activity relationships. Journal of Agricultural and Food Chemistry. vol 61(48): 11832-11839. doi: https://doi.org/10.1021/jf404641v.

Ashcroft FM, Rorsman P. 2012. Diabetes mellitus and the $\beta$ cell: the last ten years. Cell. vol 148(6): 1160 1171. doi: https://doi.org/10.1016/j.cell.2012.02.010.

Bare Y, Marhendra A, Sasase T, Fatchiyah F. 2018. Differential expression of IL-10 gene and protein in target tissues of Rattus norvegicus Strain Wistar model type 2 Diabetes Mellitus (T2DM). Acta Informatica Medica. vol 26(2): 87-92. doi: https://doi.org/10.5455/aim.2018.26.87-92

Bare Y, Rophi AH, Tiring SSNND, Rachmad YT, Nugraha FAD, Sari DRT. 2019a. Prediction potential chlorogenic acid as inhibitor ACE (In silico study). Bioscience. vol 3(2): 197-203. doi: https://doi.org/10.24036/0201932105856-0-00.

Bare Y, Sari DRT, Rachmad YT, Krisnamurti GC, Elizabeth A. 2019b. In silico insight the prediction of chlorogenic acid in coffee through Cyclooxygenase-2 (COX2) Interaction. Biogenesis: Jurnal Ilmiah Biologi. vol 7(2): 100-105. doi: https://doi.org/10.24252/bio.v7i2.9847.

Bhullar KS, Lassalle-Claux G, Touaibia M, Rupasinghe HPV. 2014. Antihypertensive effect of caffeic acid and its analogs through dual renin-angiotensinaldosterone system inhibition. European Journal of Pharmacology. vol 730: 125-132. doi: https://doi.org/10.1016/j.ejphar.2014.02.038.

Chiou SY, Sung JM, Huang PW, Lin SD. 2017. Antioxidant, antidiabetic, and antihypertensive properties of Echinacea purpurea flower extract and caffeic acid derivatives using in vitro models. Journal of Medicinal Food. vol 20(2): 171-179. doi: https://doi.org/10.1089/jmf.2016.3790.

Guang C, Phillips RD, Jiang B, Milani F. 2012. Three key proteases-angiotensin-I-converting enzyme (ACE), ACE2 and renin-within and beyond the renin-angiotensin system. Archives of Cardiovascular Diseases. vol 105(6-7): 373-385. doi: https://doi.org/10.1016/j.acvd.2012.02.010.

Hameed I, Masoodi SR, Mir SA, Nabi M, Ghazanfar K, Ganai BA. 2015. Type 2 diabetes mellitus: from a metabolic disorder to an inflammatory condition. 
World Journal of Diabetes. vol 6(4): 598-612. doi: https://dx.doi.org/10.4239\%2Fwjd.v6.i4.598.

Huang WY, Fu L, Li CY, Xu LP, Zhang LX, Zhang WM. 2017. Quercetin, hyperin, and chlorogenic acid improve endothelial function by antioxidant, antiinflammatory, and ACE inhibitory effects. Journal of Food Science. vol 82(5): 1239-1246. doi: https://doi.org/10.1111/1750-3841.13706.

Kataria R, Khatkar A. 2019. In-silico design, synthesis, ADMET studies and biological evaluation of novel derivatives of chlorogenic acid against urease protein and H. Pylori bacterium. BMC Chemistry. vol 13(1): 1-17. doi: https://doi.org/10.1186/s13065-019-0556-0.

Kesuma D, Siswandono S, Purwanto BT, Hardjono S. 2018. Uji in silico aktivitas sitotoksik dan toksisitas senyawa Turunan N-(Benzoil)-N'- feniltiourea sebagai calon obat antikanker. JPSCR : Journal of Pharmaceutical Science and Clinical Research. vol 3(1): $1-11$.

doi: https://doi.org/10.20961/jpscr.v3i1.16266.

Larson AJ, Symons JD, Jalili T. 2010. Quercetin: A treatment for hypertension?-A review of efficacy and mechanisms. Pharmaceuticals. vol 3(1): 237250. doi: https://doi.org/10.3390/ph3010237.

Liao X, Xiao J, Li SH, Xiao LL, Cheng B, Fu XB, Cui T, Liu HW. 2019. Critical role of the endogenous renin-angiotensin system in maintaining selfrenewal and regeneration potential of epidermal stem cells. Biochimica et Biophysica Acta (BBA)Molecular Basis of Disease. vol 1865(10): 26472656. doi: https://doi.org/10.1016/j.bbadis.2019.07.006.

Liu Q, Liu J, Guo H, Sun S, Wang S, Zhang Y, Li S, Qiao Y. 2013. [6]-Gingerol: A Novel AT1 antagonist for the treatment of cardiovascular disease. Planta Medica. vol 79(05): 322-326. doi: https://doi.org/10.1055/s-0032-1328262.

Liu X, Raghuvanshi R, Ceylan FD, Bolling BW. 2020. Quercetin and its metabolites inhibit recombinant human angiotensin-converting enzyme 2 (ACE2) activity. Journal of Agricultural and Food Chemistry. vol 68(47): 13982-13989. doi: https://doi.org/10.1021/acs.jafc.0c05064.

Mao QQ, Xu XY, Cao SY, Gan RY, Corke H, Beta T, Li HB. 2019. Bioactive compounds and bioactivities of ginger (Zingiber officinale Roscoe). Foods. vol 8(6):

$$
1-21 .
$$

doi: https://doi.org/10.3390/foods8060185.

Messerli FH, Bangalore S, Bavishi C, Rimoldi SF. 2018. Angiotensin-converting enzyme inhibitors in hypertension. Journal of the American College of Cardiology. vol 71(13): 1474-1482. doi: https://doi.org/10.1016/j.jacc.2018.01.058.

Muhammad SA, Fatima N. 2015. In silico analysis and molecular docking studies of potential angiotensinconverting enzyme inhibitor using quercetin glycosides. Pharmacognosy Magazine. vol 11(42):
123-126. doi: https://doi.org/10.4103/09731296.157712 .

Nileeka Balasuriya BW, Vasantha Rupasinghe HP. 2011. Plant flavonoids as angiotensin converting enzyme inhibitors in regulation of hypertension. Functional Foods in Health and Disease. vol 1(5): 172-188. doi: https://doi.org/10.31989/ffhd.v1i5.132.

Ouwerkerk W, Voors AA, Anker SD, Cleland JG, Dickstein K, Filippatos G, van der Harst P, Hillege HL, Lang CC, ter Maaten JM, Ng LL, Ponikowski P, Samani NJ, van Veldhuisen DJ, Zannad F, Metra M, Zwinderman AH. 2017. Determinants and clinical outcome of uptitration of ACE-inhibitors and beta-blockers in patients with heart failure: A prospective European study. European Heart Journal. vol 38(24): 1883-1890. doi: https://doi.org/10.1093/eurheartj/ehx026.

Sahardi NFNM, Makpol S. 2019. Ginger (Zingiber officinale Roscoe) in the prevention of ageing and degenerative diseases: Review of current evidence. Evidence-Based Complementary and Alternative Medicine. vol 2019: 1-13. doi: https://doi.org/10.1155/2019/5054395.

Sanghal A, Pant KK, Natu SM, Nischal A, Khattri S, Nath R. 2012. An experimental study to evaluate the preventive effect of Zingiber officinale (ginger) on hypertension and hyperlipidaemia and its comparison with Allium sativum (garlic) in rats. Journal of Medicinal Plants Research. vol 6(25): 4231-4238. https://doi.org/10.5897/JMPR12.323.

Santoso B, Atmajaya TE, Tirtodiharjo MK. 2016. Kajian docking senyawa 4-[(Z)-N-(4-hidroksifenil) carboksimidoil]-2- metoksifenol sebagai inhibitor Cox-2 menggunakan plants. Prosiding Seminar Nasional Kimia UNJANI-HKI 2016, August 2-4, 2016. Bandung: Hotel Grand Tjokro.

Shivanna N, Naika M, Khanum F, Kaul VK. 2013. Antioxidant, anti-diabetic and renal protective properties of Stevia rebaudiana. Journal of Diabetes and its Complications. vol 27(2): 103-113. doi: https://doi.org/10.1016/j.jdiacomp.2012.10.001.

Tarigan AR, Lubis Z, Syarifah S. 2018. Pengaruh pengetahuan, sikap dan dukungan keluarga terhadap diet hipertensi di Desa Hulu Kecamatan Pancur Batu tahun 2016. Jurnal Kesehatan. vol 11(1): 9-17. doi: https://doi.org/10.24252/kesehatan.v11i1.5107.

Zhao W, Chen Y, Xue S, Yu Z, Yu H, Liu J, Li J, Chen F. 2018. MALDI-TOF-MS characterization of Nlinked glycoprotein derived from ginger with ACE inhibitory activity. Food \& Function. vol 9(5): 2755-2761. https://doi.org/10.1039/C8FO00156A.

Zhou W, Yan H, Hao Q. 2012. Analysis of surface structures of hydrogen bonding in protein-ligand interactions using the alpha shape model. Chemical Physics Letters. vol 545: 125-131. doi: https://doi.org/10.1016/j.cplett.2012.07.016. 